\title{
Life Values and Subjective Well-being of the Indigenous Small-Numbered Peoples of the Arctic Zone (Based on the Example of the Nenets)
}

\author{
Ekaterina V.Zabelinaa, Svetlana A. Kurnosovaa, \\ Irina A. Trushina ${ }^{a}$, Natalya P. Koptseva ${ }^{b}$ \\ and Vladimir S. Luzan ${ }^{\text {** }}$ \\ ${ }^{a}$ Chelyabinsk State University \\ Chelyabinsk, Russian Federation \\ ${ }^{b}$ Siberian Federal University \\ Krasnoyarsk, Russian Federation
}

Received 02.05.2020, received in revised form 28.05.2020, accepted 05.06.2020

\begin{abstract}
The article presents the results of a study of life values and their relationship with the subjective well-being of indigenous small-numbered peoples based on the example of the Nenets. The relevance of this study is due to the fact that globalization transformations determine the change in human living conditions in the Arctic zone. This process often takes place painfully: representatives of indigenous small-numbered minorities cannot find their place in the new economic and multicultural system, which leads to the loss of vital meanings and subjective ill-being. The article notes that the solution to this problem may be to take into account life values during the transformation of the economic behaviour of the indigenous small-numbered peoples of the Russian Arctic.

The materials presented in the article demonstrate a strong relationship between the level of satisfaction with life and the subjective level of income (subjective economic wellbeing). The most important life values for the Nenets (security, kindness, independence) turned out to be connected both with the level of satisfaction with life in general and with the level of subjective economic well-being.

In conclusion, it is noted that the results obtained make it possible to formulate recommendations for various entities on the effective transformation of the economic behaviour of the indigenous small-numbered peoples of the Russian Arctic, in particular the creation of conditions for stability, social security, community and collectivism, as well as the ability to independently make economic decisions.
\end{abstract}

Keywords: transformation of economic behaviour, indigenous small-numbered peoples of the Arctic zone, life values, subjective well-being.

\footnotetext{
(C) Siberian Federal University. All rights reserved

* Corresponding author E-mail address: katya_k@mail.ru, ksa0308@mail.ru, trushina_ia@mail.ru, decanka@mail.ru, vladimir_luzan@list.ru ORCID: 0000-0003-3910-7991 (Koptseva); 0000-0002-0049-9417 (Lusan)
} 
The study was carried out with the financial support of the Russian Federal Property Fund in the framework of the scientific project No. 19-013-00394 "Transformation of the economic behaviour of the indigenous small-numbered peoples of the North living in the Arctic zone of the Russian Federation in the context of globalization."

Research area: theory and history of culture.

Citation: Zabelina, E.V., Kurnosova, S.A., Trushina, I.A. Koptseva, N.P., Luzan, V.S. (2020). Life values and subjective well-being of the indigenous small-numbered peoples of the Arctic zone (based on the example of the Nenets). J. Sib. Fed. Univ. Humanit. Soc. Sci., 13(6), 997-1006. DOI: 10.17516/19971370-0623.

Introduction. Global transformations determine a change in human living conditions in the Arctic zone. The expansion of the range of presence of the the fuel and energy complex's enterprises has led to a significant change in the familiar ecosystem. As a result, there was a reduction in the size of pastures and the impoverishment of the natural fodder base for reindeer husbandry, which is the economic basis for the livelihoods of many indigenous small-numbered peoples leading a nomadic lifestyle. First of all, these consequences were reflected in the Nenets, as this is one of the most numerous indigenous small-numbered peoples, for which reindeer husbandry is still the basis for maintaining the traditional way of life. In addition, the Nenets people have a wide range of settlement covering the Nenets Autonomous Okrug, the Yamalo-Nenets Autonomous Okrug, the Khanty-Mansi Autonomous Okrug - Ugra, the Taimyr Dolgan-Nenets Municipal District of the Krasnoyarsk Territory, the Murmansk and Arkhangelsk Regions, as well as the Komi Republic. In this regard, the study of life values and subjective well-being was based on the example of representatives of the Nenets people.

Over the past thirty years, many representatives of indigenous small-numbered minorities have been forced to change the usual traditional nomadic way of life for settled residence in towns and cities. This transformation often takes place painfully: people cannot find their place in the new economic system for them, which leads to the loss of vital meanings and subjective ill-being. The solution to this problem may be to take into account life values during the transformation of the economic behaviour of the indigenous small-numbered peoples of the Russian Arctic. Therefore, this study was initiated to identify the relationship of life values with the subjective well-being of indigenous small-numbered peoples based on the example of the Nenets.

Theoretical framework. As a general hypothesis, it was suggested that subjective well-being is associated with the most significant values for the Nenets, while the structure of the relationship of life values among the Nenets with varying degrees of subjective well-being has a distinctive quality.

The study set and solved the following tasks:

1. Theoretically and empirically to substantiate the construct of subjective well-being as an indicator of satisfaction with the life of indigenous peoples, including in the economic sphere;

2. To identify the most significant life values for the Nenets;

3 . To establish the relationship of life values with the level of satisfaction with life and subjective economic well-being (subjective level of income);

4. To compare the life values of the Nenets with a different level of subjective well-being;

5. To compare the structure of the relationship of life values among the Nenets with a different level of subjective well-being.

Methods. To test the hypothesis, a study was conducted in which 105 people, who were representatives of the Nenets nationality aged 17 to 73 years (average age - 28.6), took part, including 42 men, 63 women living in the Yamalo-Nenets Autonomous Okrug (Aksarka vil- 
lage, Yar-Sale village) and the Nenets Autonomous Okrug (Naryan-Mar city, Nes' village, Krasnoye village).

An extended and updated version of the Shalom Schwartz PVQ-R questionnaire adapted by employees of the Higher School of Economics (Schwartz et al., 2012) was used as a method for diagnosing life values. Today it is one of the most popular methods for the diagnosis of motives and values, which has confirmed its validity in various categories of the Russian sample. The convenience of this method's variant is that along with the 19 specified values, it provides the opportunity to diagnose 10 basic values identified in the original concept (Schwartz, Bilsky, 1987), thereby making comparisons with previous studies.

To diagnose subjective well-being, the Life Satisfaction Scale of E. Diener adapted by D.A. Leont'ev and E.N. Osin was used (Osin, Leont'ev, 2008). This questionnaire has proven itself in the Russian sample due to its simple and unambiguous internal structure. The "Life Satisfaction Scale" methodology, developed by E. Diener in accordance with its theoretical principles, allows measuring the level of subjective well-being and comparing the performance of different people, demonstrating how one person is more prosperous, more satisfied, more positive than another (Litvina, Bogomaz, 2014).

In addition to the data from the questionnaires, the study used a scale of A. Furnham's subjective income level adapted by O.S. Deineka (Deineka, 1999). Respondents were asked to rate their income on a 7-point scale, where 1 - I make ends meet, and 7 - I have a very high income. This technique is widely used in studies of economic psychology as an indirect indicator of a person's subjective economic well-being.

For mathematical and statistical data processing, descriptive statistics, the Kruskal - Wallis difference H-criterion, and the $\mathrm{R}$ - Spearman correlation analysis were used. In addition, when processing the data, the statistical data processing package SPSS 24.0 was used.

The solution to the first problem led to the appeal to the concepts of subjective well-being, presented in modern scientific knowledge. The concept of subjective well-being of E. Diener is widely known in the world and received enough empirical confirmation. According to it, the subjective well-being of a person consists of three fundamental components: satisfaction, pleasant emotions and unpleasant emotions. In addition, E. Diener believes that subjective well-being reflects a person's cognitive assessment of the conformity of his/her life's different aspects to the formed expectations, the level of self-acceptance and is found in emotional manifestations (experienced feelings, typical mood). Moreover, a person has a high level of subjective well-being, if in most situations he / she experiences satisfaction with life, and only in some cases experiences unpleasant feelings, and vice versa (Diener, Lucas, 1999).

Despite the good indicators of the validity and reliability of this construct, it should be noted that it gives a very general view of human well-being, without being able to determine the level of satisfaction with a particular area of life. At the same time, more specific concepts of subjective well-being, for example, subjective economic well-being, have been developed in psychological science (Deineka, 1999; Khashchenko, 2011; Furnham, 2014).

Subjective economic well-being is defined as a result of a social comparison of a person's actual status with his claims, needs and perception of his own position (Strümpel, 1974) or with the financial situation of other reference persons (Campbell, Converse, Rodgers, 1976). V.A. Khashchenko defines subjective economic well-being as "an integral psychological indicator of a person's life expressing a person's attitude to his current and future material well-being" (Khashchenko, 2011: 108).

Discussion. As a result, there was an assumption that the subjective economic well-being of a person is associated with satisfaction with life as a whole, as a component of his overall subjective well-being. The results of the correlation analysis on a sample of Nenets confirmed this assumption (Table 1).

In fact, satisfaction with life as a whole as an indicator of subjective well-being and a subjective assessment of one's income as an indicator of subjective economic well-being pos- 
Ekaterina V. Zabelina, Svetlana A. Kurnosova... Life Values and Subjective Well-being of the Indigenous...

Table 1 . The results of the correlation analysis of the level of subjective income and life satisfaction

\begin{tabular}{|c|c|c|}
\hline \multirow{2}{*}{ Subjective assessment of income } & Subjective assessment of income & Life satisfaction \\
\cline { 2 - 3 } & 1,000 &, $375^{* *}$ \\
\hline \multirow{2}{*}{ Life satisfaction } & & 0,002 \\
\cline { 2 - 3 } &, $375^{* *}$ & 1,000 \\
\hline
\end{tabular}

Table 2. Descriptive statistics of vital values' indicators

\begin{tabular}{|c|c|c|c|c|c|c|}
\hline Indicators & $\mathrm{N}$ & Min & Max & Average & Standard error & Dispersion \\
\hline Security & 105 & 1,00 & 7,00 & 4,5079 & 1,22199 & 1,493 \\
\hline Kindness & 105 & 1,00 & 6,67 & 4,4571 & 1,35972 & 1,849 \\
\hline Independence & 105 & 1,00 & 6,83 & 4,3190 & 1,41461 & 2,001 \\
\hline Achievements & 105 & 1,00 & 7,00 & 4,2730 & 1,25812 & 1,583 \\
\hline Universalism & 105 & 1,00 & 6,67 & 4,1608 & 1,26752 & 1,607 \\
\hline Traditions & 105 & 1,00 & 6,83 & 4,0921 & 1,29512 & 1,677 \\
\hline Hedonism & 105 & 1,00 & 6,67 & 4,0857 & 1,20276 & 1,447 \\
\hline Conformity & 105 & 1,00 & 6,83 & 3,9429 & 1,25103 & 1,565 \\
\hline Stimulation & 105 & 1,00 & 7,00 & 3,6764 & 1,45941 & 2,130 \\
\hline Power & 105 & 1,00 & 7,00 & 3,2386 & 1,39744 & 1,953 \\
\hline
\end{tabular}

itively correlate with each other at a high level of statistical significance. At the next stage, using descriptive statistics, the most significant life values for the Nenets were determined (Table 2).

As can be seen from the table, the Nenets consider security, kindness and independence to be the most important life values. Security for oneself and other people, harmony in relations, stability of society are the most important value priorities of the Nenets people. This fact, largely due to the harsh climatic conditions of living in the North, is confirmed by many researchers (Dregalo, Ul'ianovskii, 2016; Etnonacional'nye protsessy v Arktike..., 2017; Pavlenko et al., 2017; Brega, 2018, etc.). Probably, the same factor (understanding of the vulnerability and value of human life) is associated with the desire to ensure well-being in everyday interaction with loved ones, the need for positive interaction with them, friendly support, and mutual assistance. Under these conditions, the ability to independently think and make deci- sions, the desire to independently choose methods of action, to show creativity and research activity is of particular importance, therefore, the need for self-control and self-government is important.

To solve the third problem, a correlation analysis of the relationship of the Nenets life values with their level of satisfaction with life and subjective economic well-being (subjective income level) was carried out (Tables 3 and 4).

As can be seen from the tables, the level of satisfaction with life among the Nenets is interconnected with all significant values - security, kindness, independence and some others, while the subjective level of income shows the relationship only with the value of independence.

The data obtained allow us to suggest that money, material values, profit and other indicators of financial status are not so closely woven into the value system of the Nenets as compared to satisfaction with life in general. Only the desire to think and make decisions on one's own, independently of others, allows 
Table 3. The results of the correlation analysis of indicators of life values and life satisfaction among representatives of the Nenets

\begin{tabular}{|l|c|c|c|c|c|c|c|c|c|c|}
\hline & $\begin{array}{c}\text { Con- } \\
\text { formity }\end{array}$ & $\begin{array}{c}\text { Tradi- } \\
\text { tions }\end{array}$ & $\begin{array}{c}\text { Kind- } \\
\text { ness }\end{array}$ & $\begin{array}{c}\text { Univer- } \\
\text { salism }\end{array}$ & $\begin{array}{c}\text { Inde- } \\
\text { pen- } \\
\text { dence }\end{array}$ & $\begin{array}{c}\text { Stimu- } \\
\text { lation }\end{array}$ & $\begin{array}{c}\text { Hedo- } \\
\text { nism }\end{array}$ & $\begin{array}{c}\text { Achieve- } \\
\text { ments }\end{array}$ & $\begin{array}{c}\text { Power } \\
\text { Secu- } \\
\text { rity }\end{array}$ \\
\hline $\begin{array}{l}\text { Life satis- } \\
\text { faction, R }\end{array}$ &, $242^{*}$ &, $276^{*}$ &, $259^{*}$ &, $251^{*}$ &, $330^{* *}$ &, $298^{*}$ & 0,092 & 0,152 & 0,211 &, $240^{*}$ \\
\hline $\mathrm{p}$ & 0,047 & 0,023 & 0,033 & 0,039 & 0,006 & 0,014 & 0,455 & 0,216 & 0,084 & 0,049 \\
\hline
\end{tabular}

Table 4. The results of the correlation analysis of life values' indicators and subjective income level

\begin{tabular}{|l|c|c|c|c|c|c|c|c|c|c|}
\hline & $\begin{array}{c}\text { Con- } \\
\text { formity }\end{array}$ & $\begin{array}{c}\text { Tradi- } \\
\text { tions }\end{array}$ & $\begin{array}{c}\text { Kind- } \\
\text { ness }\end{array}$ & $\begin{array}{c}\text { Univer- } \\
\text { salism }\end{array}$ & $\begin{array}{c}\text { Inde- } \\
\text { pen- } \\
\text { dence }\end{array}$ & $\begin{array}{c}\text { Stimu- } \\
\text { lation }\end{array}$ & $\begin{array}{c}\text { Hedo- } \\
\text { nism }\end{array}$ & $\begin{array}{c}\text { Achieve- } \\
\text { ments }\end{array}$ & \begin{tabular}{c} 
Power \\
rity \\
\hline
\end{tabular} \\
\hline $\begin{array}{l}\text { Subjective } \\
\text { income, } \mathrm{R}\end{array}$ & 0,100 & 0,040 & 0,128 & 0,087 &, $235^{*}$ & 0,127 & $-0,026$ & 0,055 & 0,112 & 0,151 \\
\hline $\mathrm{p}$ & 0,314 & 0,686 & 0,194 & 0,381 & 0,017 & 0,198 & 0,792 & 0,580 & 0,258 & 0,125 \\
\hline
\end{tabular}

respondents to rate their income level as higher. On the contrary, the Nenets, who are inclined to assess their income level as below average and low, show less desire to make independent decisions and to carry out independent actions. This psychological feature of the Nenets people has already been shown in a number of studies. In particular, the relationship of the value of independence with a positive attitude to the personal achievements of other people in the economic sphere, as well as with other economic attitudes (Zabelina et al., 2019) is revealed.

The Nenets, who are more satisfied with their lives, are much more active in maintaining security and stability in society, ensuring prosperity for their loved ones, achieving success in socially acceptable ways, expressing independence in thoughts and actions, preserving the customs and ideas that exist in traditional culture, and following them. Tolerance and protection of the well-being of all people and nature, as well as the need for novelty and emotional experiences are typical of them.

Further, in order to solve the fourth problem, the entire sample was divided into three groups according to the criterion of subjective well-being based on descriptive statistics (mean value $=3.91$, standard error $=1.4$ ). Groups were conditionally named as respondents with high, medium, and low levels of subjective well-being. Further, in these groups, indicators of life values were compared.

The comparison results did not reveal significant differences in the life values of the $\mathrm{Ne}$ nets with different levels of subjective well-being, although they showed a tendency to higher values of security, independence and traditions among respondents with a high level of subjective well-being.

Next, a comparison of correlation constellations (intercorrelations of life values and correlations with the level of subjective income) was made in groups with a high and low level of subjective well-being.

The comparison results confirmed the hypothesis about the qualitative uniqueness of the structure of life values depending on the level of subjective well-being. In particular, the value of hedonism in a group with a higher level of subjective well-being finds a connection only with the value of power, while in a group with a lower level of subjective well-being - with the values of power, security and universalism. Perhaps, the desire to enjoy "here and now", without thinking about the consequences, reinforced by the desire for security, tolerance 
and the desire for the well-being of all people and nature, does not allow respondents to actually feel satisfaction with life. It can also be assumed that these motives are not embodied in real actions, which prevents the personal situation from changing for the better.

Confirmation of this assumption is found in another correlation constellation. Thus, in the group of Nenets with a higher level of subjective well-being, the value of achievement is associated with the value of power, and in the group with a lower level of subjective well-being, no relationship with the value of achievement was found. Probably, the desire to achieve personal success, reinforced by the desire to dominate the situation and other people, allows achieving goals in life, which leads to increased satisfaction with life in general.

Against the background of a small number of relationships with the value of power in the group of respondents with a low level of subjective well-being, the relationship of this value with the security value in the group of respondents with a high degree of subjective well-being seems interesting. The combination of the desire to protect themselves, their loved ones, society as a whole and the desire to dominate the situation and other people gives rise to self-confidence and willingness to use available resources to ensure social stability. This, in turn, leads to increased satisfaction with life.

It is interesting that there were correlations between the level of subjective income and the values of conformity, universalism and stimulation in the group of Nenets, less satisfied with their lives, while in the group of Nenets with a high level of subjective well-being, the relationship of life values with the level of income was not found. Probably, a closer connection of the economic component in subjective well-being with personal motives and aspirations, the measurement of success by money leads to a decrease in the level of satisfaction with life among the Nenets as a whole.

Therefore, it can be assumed that a change in the economic situation of the indigenous small-numbered peoples of the Russian Arctic (financial instability, a threat to the traditional way of life, the development of commodity-money relations, the aggravation of financial needs, the popularization of material values, etc.) leads to a decrease in the level of subjective well-being.

Conclusion. The study allows us to formulate a number of conclusions. Firstly, it has been established that the subjective economic well-being of the Nenets, closely associated with general satisfaction with life, weakly affects the value sphere of their personality. In this sense, the influence of globalization with the cult of material values has not fully overtaken the representatives of this people. On the other hand, the connection of life values with the assessment of their income in a group of respondents less satisfied with their lives allows us to conclude that focusing on achieving financial success does not lead to the subjective well-being of the indigenous small-numbered peoples of the North. This problem raises the question of the possible absence of cognitive and behavioural mechanisms that allow the Nenets to successfully adapt to the changing economic situation.

The value of independence that is the desire for independence in thinking and acting can be considered an important resource that allows the Nenets to effectively build their economic behaviour. The development of the value of independence in children and youth of indigenous small-numbered peoples based on financial literacy can become the basis for the successful transformation of the economic behaviour of these peoples in the context of globalization.

In addition, since the subjective well-being of the Nenets is largely based on the values of security and kindness, it is necessary to take this factor into account when developing programs for transforming the economic behaviour of the indigenous small-numbered peoples of the North, providing conditions for economic stability, social security, a sense of community and collectivism.

In conclusion, it is worth noting that a significant limitation of the study is a small sample of representatives of one nation - the $\mathrm{Ne}$ nets. In the future, it is necessary to expand the sample by including representatives of other indigenous small-numbered minorities of the Russian Arctic in the study. 


\section{References}

Armitage, C.J., Conner, M. (2000). Attitudinal ambivalence: a test of three key hypotheses. In Personality and Social Psychology Bulletin, 26, 1421-1432.

Brega, G.V. (2018). Etnicheskie osobennosti ekonomicheskogo povedeniia. [Ethnic features of economic behavior]. «Prometei», $171 \mathrm{p}$.

Borisov, V.N., Pochukaeva, O.V. (2016). Vzaimosviazi faktorov razvitiia Arkticheskoi zony RF [Interrelations of factors of development of the Arctic zone of the Russian Federation]. In Problemy prognozirovaniia [Forecasting problems], 2, 59-68.

Campbell, A., Converse, P., Rodgers, W. (1976). The Quality of American Life: Perceptions, Evaluations and Satisfactions. N. Y., 1976, 600 p.

Deineka, O.S. (1999). Ekonomicheskaia psihologiia: sotsial'no-politicheskie problemy [Economic psychology: socio-political problems]. Saint-Petersburg, SPbGU.

Deineka, O.S. (2011). Ekonomicheskoe soznanie: fenomenologiia, struktura i potenzial razvitiia [Economic consciousness: phenomenology, structure and potential of development]. In Kul'tura i ekonomicheskoe povedenie: sbornik statei [Culture and Economic Behavior: A Collection of Articles]. Moscow, Maks Press, 118-148.

Deineka, O.S., Zabelina, E.V. (2018). Rezul'taty razrabotki shkal'nogo mnogofaktornogo oprosnika dlia ekspress-diagnostiki ekonomicheskikh attitiudov [Results of development of the school multiple-factor questionnaire for express diagnostics of economic attitudes]. In Psikhologicheskie issledovaniia [Psychological research], 11 (58), 9. Available at: http://psystudy.ru

Detter, G.F. (2018). Formirovanie funktsional'no polnoi innovatsionnoi infrastruktury v ekosisteme arkticheskikh regionov [Formation of functionally full innovative infrastructure in the ecosystem of the Arctic regions]. In Voprosy innovatsionnoi ekonomiki [Innovation Economy Issues], 8 (1), 91-104.

Detter, G.F. (2019). Ekonomicheskoe povedenie korennykh malochislennykh narodov Severa Rossii: postanovka problem [Economic behavior of the indigenous peoples of the Russian north: statement of the problem]. In Vestnik Cheliabinskogo gosudarstvennogo universiteta [Bulletin of Chelyabinsk State University], 9 (431), 32-42.

Diener, E., Lucas, R.E. Personality and subjective well-being // Well-being: The foundations of hedonic psychology. N. Y., 1999. P. 213-229.

Dregalo, A.A., Ul'ianovskii, V.I. (2016). Inertsionnye protsessy v obshchestvennom soznanii Severnogo regiona Rossii [Inertial processes in public consciousness of the Northern region of Russia]. In Materialy mezhdunarodnoi nauchno-prakticheskoi konferentsii «Monitoring $i$ otsenka razvitiia territorii Arkticheskoi zony» [Materials of the International Research-to-Practice conference "Monitoring and evaluation of the development of the Arctic zone”]. Arkhangelsk, «KIRA», 304-306.

Etnonatsional'nye protsessy $v$ Arktike: tendentsii, problemy i perspektivy: monografia [Ethnonational processes in the Arctic: trends, problems and prospects] (2017). Arhangelsk, SAFU, 325 p.

Furnham, A. (1996). Attitudinal correlates and demographic predictors of monetary beliefs and behaviors. In Journal of Organizational Behavior, 17 (4), 375-388.

Furnham, A. (2014). The new psychology of money. London: Routledge.

Khashchenko, V.A. (2011). Sub'ektivnoe ekonomicheskoe blagopoluchie i ego izmerenie: postroenie oprosnika i ego validizatsiia [Subjective economic well-being and its measurement: constructing and validating a questionnaire]. In Eksperimental'naia psikhologiia [Experimental psychology], 4 (1), $106-127$.

Khashchenko, V.A. (2005). Ekonomiko-psikhologicheskaia model' sub'ektivnogo ekonomicheskogo blagopoluchiia [Economic-psychological model of subjective economic well-being]. In Psikhologicheskii zhurnal [Psychological Journal], 26 (4), 5-19.

Khariuchi, G.P., Petrova, V.P. (2014). Nentsy v istorii Iamala [Nenets in the history of Yamal]. In Nauchnyi Vestnik Iamalo-Nenetskogo avtonomnogo okruga [Scientific Bulletin of the Yamal-Nenets Autonomous Okrug], 3(84), 55-59. 
Koptseva, N.P., Sergeeva, N.A., Ermakov, T.K. (2018). Sovremennye sposoby etnicheskoi samoidentifikatsii na materiale analiza evenkiiskoi etnokul'turnoi gruppy [Modern ways of ethnic self-identification based on the analysis of the Evenki ethnocultural group]. In Spetsifika etnicheskikh migratsionnykh protsessov na territorii tsentralnoi Sibiri v XX-XXI vekakh: opyt i perspektivy [Specificity of ethnic migration processes in the territory of central Siberia in the $20^{\text {th }}-21^{\text {st }}$ centuries: experience and prospects]. Krasnoyarsk, Sibirskii Federal'nyi universitet, 195-198.

Lewis, A., Webley, P., Furnham, A. The new economic mind: the social psychology of economic behavior. N. Y. 1995.

Leksin, V.N., Porfir'ev, B.N. (2015). Nauchnyi i institutsional'nyi potentsial kompleksnogo razvitiia rossiiskoi Arktiki v sredne- i dolgosrochnoi perspective [Scientific and institutional potential of complex development of the Russian Arctic in the average and long term]. In Problemy prognozirovaniia [Forecasting Problems], 6, 58-66.

Litvina, S.A., Bogomaz, S.A. (2014). Individual'nye dostoinstva kak prediktory udovletvorennosti cheloveka svoei zhizn'iu [Personal virtues as predictors of life satisfaction]. In Sibirskii psikhologicheskii zhurnal [Siberian Psychological Journal], 211-219.

Luzan, V.S. (2018). Practical Aspects of Cultural Policy in Ethnic Administrative Territorial Units. In Facets of Culture in the Age of Social Transition: Proceedings of the All-Russian Research Conference with International Participation. KnE Engineering, 99-103.

Luzan, V.S., Koptseva, N.P., Zabelina, E.V., Kurnosova, S.A., Trushina, I.A. (2019). The Structure of Economic Attitudes of the Youth - Representatives of the Indigenous Small-Numbered Peoples of the Arctic Zone of the Russian Federation: Results of a Pilot Study. In Journal of Siberian Federal University. Humanities \& Social Sciences, 12 (6), 1146-1162.

Mewse, A.J., Lea, S.E.G., Wrapson, W. (2010). First steps out of debt. Attitudes and social identity as predictors of contact by debtors with creditors. In Journal of Economic Psychology, 31 (6), 1021-1034.

Osin, E.N., Leont'ev, D.A. (2008). Aprobtsiia russkoiazychnykh versii dvukh shkal ekspress-otsenki sub"ektivnogo blagopoluchiia [Testing Russian-language versions of two scales of rapid assessment of subjective well-being]. Moscow, Institut sotsiologii RAN, Rossiiskoe obshchestvo sociologov.

Osipova, O.V. (2014). Izmenenie zhiznenykh strategii i ekonomicheskogo povedeniia molodezhi Arktiki [Change of vital strategy and economic behavior of youth of the Arctic]. In Arktika i sever [The Arctic and the North], 14.

Pavlenko, V.I., Dregalo, A.A., Ul'ianovskii, V.I., Kutsenko, S.IU., Malinina, K.O., Balitskaia, S.M. (2017). Metodologicheskie osobennosti sotsial'no-ekonomicheskikh issledovanii Arkticheskoi zony Rosiiskoi Federatsii [Methodological features of social and economic researches of the Arctic zone of the Russian Federation]. In Izvestiia Komi nauchnogo tsentra UrO RAN [Bulletin of Komi Research Center], 1 (29).

Rossiiskaia Arktika: korennye narody i promyshlennoe osvoenie. Pod red. V.A. Tishkova [Russian Arctic: indigenous people and industrial development. Edited by V.A. Tishkov] (2016). Moscow, St. Petersburg, Nestor-Istoriia, 272.

Schwartz, Sh., Butenko, T.P., Sedova, D.S. (2012). Utochnennaia teoriia bazovykh individual'nykh tsennostei: primenenie v Rossii [Theory of Basic Personal Values: Validation in Russia]. In Psikhologiia. Zhurnal Vysshei shkoly ekonomiki [Psychology. Journal of the Higher School of Economics], 9 (1), 43-70.

Schwartz, Sh., Bilsky, W. (1987). Toward a universal psychological structure of human values. In Journal of Personality and Social Psychology, 53, 550-562.

Schwartz, Sh., Butenko, T.P, Sedova, D.S, Lipatova, A.S. (2012). A refined theory of basic individual values: application in Russia, Psychology. In Journal of the Higher School of Economics, 9 (1), 43-70.

Strümpel, B. (1974). Economic well-being as an object of social measurement. Paris: Organization for Economic Cooperation and Development. P. 75-122.

Zabelina, E., Deyneka, O., Tsiring, D. (2019). Entrepreneurial attitudes in the structure of students' economic minds. In International Journal of Entrepreneurial Behavior \& Research, available at: https:// doi.org/10.1108/IJEBR-04-2018-0224 
Zabelina, E.V., Kurnosova, S.A. (2018). Osobennosti ekonomicheskogo soznaniia predstavitelei korennykh malochislennykh narodov Arkticheskoi zony: rezul'taty pilotnogo issledovaniia molodezhi [Features of economic consciousness of indigenous ethnic groups' representatives of the Arctic zone: results of a pilot research of youth]. In Peterburgskii psikhologicheskii zhurnal [Petersburg Psychological Journal], 23. Available at http://ppj.spbu.ru/index.php/psy/article/view/203

Zabelina, E.V., Kurnosova, S.A., Telitsina, A.Iu., Shchukina, K.E. (2019). Vzaimosviaz' ekonomicheskikh attitiudov i zhiznennykh tsennostei u predstavitelei korennykh malochislennykh narodov Rossiiskoi Arktiki (na materiale issledovaniia nentsev) [Interrelation between economic attitudes and life values of the indigenous small-numbered peoples of the Russian Arctic (based on the Nenets sample)]. In Vestnik MGOU [Bulletin of the Moscow State Region University], 3, 105-115.

\title{
Жизненные ценности и субъективное благополучие у коренных малочисленных народов Арктической зоны (на примере ненцев)
}

\author{
Е.В. Забелинаа, С.А. Курносова, И.А.Трушина, \\ Н.П. Копцева ${ }^{6}$, В.С. Лузан \\ аЧелябинский государственный университет \\ Российская Федерачия, Челябинск \\ ${ }^{6}$ Сибирский федеральный университет \\ Российская Федераичия, Красноярск
}

\begin{abstract}
Аннотация. В статье представлены итоги исследования жизненных ценностей и их связи с субъективным благополучием коренных малочисленных народов на примере ненцев. Актуальность данного исследования обусловлена тем, что глобализационные трансформации детерминируют изменение условий жизни человека в Арктической зоне. Данный процесс часто проходит болезненно: представители коренных малочисленных народов не могут найти свое место в новой для них экономической и поликультурной системе, что приводит к утрате жизненных смыслов и субъективному неблагополучию. В статье отмечается, что решением данной проблемы может стать учет жизненных ценностей в ходе трансформации экономического поведения коренных малочисленных народов Российской Арктики.

Представленные в статье материалы демонстрируют наличие сильной взаимосвязи между уровнем удовлетворенности жизнью и субъективным уровнем дохода (субъективного экономического благополучия). Наиболее важные для ненцев жизненные ценности (безопасность, доброта, самостоятельность) оказались связаны как с уровнем удовлетворенности жизнью в целом, так и с уровнем субъективного экономического благополучия.

В заключение отмечается, что полученные результаты позволяют сформулировать рекомендации для различных субъектов по эффективной трансформации экономического поведения коренных малочисленных народов Российской Арктики, в частности, создания условий стабильности, социальной защищенности, общности и коллективизма, а также возможности самостоятельно принимать экономические решения.
\end{abstract}


Ключевые слова: трансформация экономического поведения, коренные малочисленные народы Арктической зоны, жизненные ценности, субъективное благополучие.

Исследование выполнено при финансовой поддержке РФФИ в рамках научного проекта № 19-013-00394 «Трансформация экономического поведения коренных малочисленных народов Севера, проживающих на территории Арктической зоны Российской Федерации в условиях глобализации».

Научная специальность: 24.00.01 - теория и история культуры. 